\title{
Fiscal Decentralization and Environmental Pollution Control
}

\author{
Cordelia Onyinyechi Omodero
}

Department of Accounting, College of Management and Social Sciences, Covenant University Ota, Ogun State 110001, Nigeria

Corresponding Author Email: onyinyechi.omodero@covenantuniversity.edu.ng

https://doi.org/10.18280/ijsdp.160718

Received: 22 August 2021

Accepted: 10 October 2021

\section{Keywords:}

fiscal decentralization, pollution control, $\mathrm{CO}_{2}$ emission, environmental economics, JEL classification codes: H77, Q50

\begin{abstract}
Fiscal decentralization is one of the strategies applied to involve both the national and local governments in environmental management. Although, this study tries to examine its effectiveness in Nigeria which has been ambiguous. Using a multiple regression method, the study examines the effect of revenue fiscal structure on $\mathrm{CO}_{2}$ emission management in Nigeria from 2007 to 2020. Controlling pollution through the fiscal system is exceedingly difficult. According to the t-statistic results, it is only the central government that has a significant favorable influence on pollution management. State and local governments have a minimal impact on $\mathrm{CO}_{2}$ emissions reduction. This outcome leads to a suggestion that resource accumulation powers should be equitable with a higher consideration to the state and local governments which have a greater burden of controlling pollution in the rural areas where majority of the citizens have their abodes. The government at all levels should guarantee that the country's environmental policies and regulations are effectively implemented in order to reduce carbon emissions and other types of environmental pollution.
\end{abstract}

\section{INTRODUCTION}

Environmental innovation, as the major driving force for green development, aims to promote the study, diffusion, and implementation of green technology in order to accomplish the synchronization of environmental protection and economic development [1-3]. The challenges of resources, environment, and ecology have grown increasingly significant as the global economy has developed [4, 5]. Due to efforts to promote environmental protection that guarantees pollution free vicinity, green development has become an essential component of this long-term development. The widespread usage of fossil energy has resulted in severe environmental contamination, which is incompatible with the notion of sustainable development [6, 7]. Traditional energy usage has dropped in recent years when compared to renewable energy, yet it is still the primary energy source utilized in industrial production [8]. As spending decentralization rises, local governments invest limited funds in more productive infrastructure sectors rather than environmental protection [9], resulting in insufficient environmental protection expenditures. As a result, environmental protection expenditures rise, as does the rate of marginal change in environmental investment [10].

Fiscal decentralization is likely to be an inherent element influencing government spending on environmental protection, which has a significant impact on environmental innovation at the same time [3]. According to $\mathrm{He}$ [11], fiscal decentralization has a considerable favorable influence on pollution treatment costs and pollutant discharge fees. That is, decentralization of national financing can maximize the impact of industrial policies on implementation [12] and improve local environmental governance [11]. Although some researchers have not explicitly examined the influence of revenue fiscal decentralization on environmental pollution control in emerging countries, they have shown how fiscal decentralization impacts government expenditures on environmental protection. However, the dynamic effect of revenue fiscal decentralization on pollution management is yet to be clarified. Actually, fiscal decentralization has a complicated impact on environmental systems [13]. This is due not just to the complexity of the environmental system, but also to the impact of regional features. The growth in regional inequality has diminished the incentive impact of spending decentralization [9]. You et al. [14] argued that fiscal decentralization undermines environmental regulation's role in encouraging environmental innovation in China. Others, on the other hand, believe that decentralization of expenditures can offer local governments more authority in managing local matters [3]. Local governments have a lot of leeway and flexibility when it comes to environmental management [15].

To this end, no comprehensive research has been conducted on the influence of income fiscal decentralization in controlling environmental pollution in less industrialized economies. Studies from emerging nations like Nigeria with a well-defined revenue and expenditure fiscal decentralization and having a high density of human population and environmental pollution are still very scarce. Due to the oil and gas companies' activities and use of fossil fuels (Coal, Oil and Gas) as the major source of energy in Nigeria, environmental pollution has been at a very high degree. The Niger Delta regions in Nigeria have the most painful story to tell as regards $\mathrm{CO}_{2}$ emission from glass flaring and oil drilling activities. The purpose of fiscal decentralization in Nigeria is to ensure that environmental cleaning is adequately done to preserve the environs and make it conducive for the inhabitants. Therefore, 
this present study is aimed at determining the effect of revenue fiscal decentralization on environmental pollution management evidenced in $\mathrm{CO}_{2}$ emission control in all the regions in Nigeria.

\section{LITERATURE REVIEW}

By examining water contamination in rivers throughout the world, Sigma [16] investigated the empirical impacts of decentralization on environmental quality. The study investigated the amount of pollution and variance in pollution between jurisdictions within a country for a local and a regional pollutant. Federal nations had higher interjurisdictional variance in pollution, lending credence to the conventional idea that decentralization is acceptable for better customized measures to local situations. The study indicated no "race to the bottom" in pollutant levels. Contrary to the findings of Sigma $[16,17]$ extended the study by using the geographic Durbin model to examine the influence of fiscal decentralization on environmental pollution. The investigation measured fiscal decentralization with both the standpoints of fiscal spending decentralization and fiscal revenue decentralization. The findings indicated that fiscal decentralization had a beneficial influence on environmental degradation and that a "race to the bottom" phenomena occurred.

Following the China's economic progress which was hampered by environmental degradation, in terms of fiscal decentralization, China implemented a rule-based tax assignment system in 1994. As a result, He [11] employed provincial panel data from 1995 to 2010 to avoid fundamental changes in the underlying budgetary regimes. Thus, using a system GMM (Generalized method of moments) estimation, the study found that fiscal decentralization had no substantial influence on environmental pollution as assessed by per capita emissions of wastewater, waste gas, or solid waste. The study also applied alternative metrics of fiscal decentralization, and the results remained consistent. It was also discovered that fiscal decentralization had a large, beneficial influence on pollution abatement spending and pollutant discharge fees, indicating plausible pathways for fiscal decentralization to aid in environmental protection. Khan et al. [18] used a balanced panel dataset of seven OECD nations between 1990 and 2018, to analyze the influence of fiscal decentralization on $\mathrm{CO}_{2}$ emissions. In addition, the study investigated the roles of institutions and human capital in the impact of fiscal decentralization on $\mathrm{CO}_{2}$ emissions. In addition to the direct impact, it was expected that fiscal decentralization could have an indirect influence on $\mathrm{CO}_{2}$ emissions via multiple channels such as institutions and human capital. According to the empirical findings, fiscal decentralization enhanced environmental quality. The further disclosed that increases in institutional quality and human capital development reinforced the link between fiscal decentralization and environmental quality.

Zhou et al. [3] examined the effects of fiscal decentralization on environmental innovation using Chinese province panel data from 2007 to 2017. The investigation focused on the regulatory role of government environmental protection expenditures using the mediator impact model. The empirical study demonstrated that fiscal decentralization did not only directly boosted environmental innovation, but it also indirectly weakened environmental innovation through local government environmental protection spending. Fiscal decentralization encouraged environmental innovation, according to the overall performance. The study also revealed that the impact on China's east was much greater than in the country's center and western areas. Wang et al. [19] used slack-based measure-data envelopment analysis (SBM-DEA) approach to assess energy efficiency, and the spatial Durbin model was used to examine the geographic spill-over impacts of fiscal decentralization, industrial structure, and energy efficiency. According to the findings, China's energy efficiency has a distinct geographical step distribution, with the Eastern and Western areas having better energy efficiency than the Central region. By improving the industrial structure, fiscal decentralization improved the energy efficiency of the Eastern and Central regions. Furthermore, fiscal decentralization produced large beneficial externalities on the neighboring areas, encouraging environmental protection and energy conservation throughout China.

Guo et al. [20] studied the impact of fiscal decentralization on environmental pollution in China's provinces, as well as the role of government environmental preference. According to the data, decentralization of fiscal revenue increases local environmental degradation more than decentralization of spending. Zhou and Zhang [21] used both fiscal expenditure policy and fiscal revenue policy as input indicators and selected environmental pollution control results reflecting different forms and sources of pollution as output indicators. The efficiency of fiscal policies for environmental pollution control (EFPE) of 30 provincial-level administrative divisions in China from 2007 to 2017 was measured by adopting the data envelopment analysis (DEA) method. Then, the spatial effect of fiscal decentralization on EFPE is empirically analyzed by using the spatial lag model (SLM). The results show that EFPE values in China had been greatly improved overall since 2014 . The change in technical efficiency (TE) was caused mainly by the change in pure technical efficiency (PTE). EFPE values had regional heterogeneity and convergence.

Phan et al. [22] examined the dynamic influence of fiscal decentralization on $\mathrm{CO}_{2}$ emissions in nine Asian nations from 1984 to 2017 using a new dynamic panel ARDL model. According to the empirical data, fiscal decentralization had asymmetric impacts on $\mathrm{CO}_{2}$ emissions since a positive shift in income and spending decentralization lowered $\mathrm{CO}_{2}$ emissions in Asia. Furthermore, a negative shift in spending decentralization had increased $\mathrm{CO}_{2}$ emissions in the long run. Thus, based on nonlinear results in the contemporary age, clean environmental policies and suggestions might be changed and presented. Chen et al. [23] used cluster analysis, a spatial within between logarithmic mean Divisia index decomposition models was created to assess the possible impact of fiscal decentralization in generating interprovincial variations in $\mathrm{CO}_{2}$ emissions in China. According to the findings, the direct influence of fiscal decentralization emerged as a key emission driver after 2009. The variations in province $\mathrm{CO}_{2}$ emissions from the national average can be ascribed mostly to emission disparities between provincial clusters. Fiscal decentralization's direct and indirect effects shaped disparities in $\mathrm{CO}_{2}$ emissions between provinces and their provincial cluster average, as well as between provincial cluster average and national average.

The asymmetric relationship between fiscal decentralization, environmental innovation, and carbon emissions in highly decentralized nations is investigated in this paper. As a result, Lingyan et al. [24] employed a unique 
empirical estimate approach known as Method of Moments Quantile Regression to cope with non-normality and structural alterations at the same time. The findings showed that fiscal decentralization significantly reduced carbon emissions only at the low to medium emission quantiles. Environmental innovation, on the other hand, decreased carbon emissions only at the medium to high emission quantiles. Surprisingly, fiscal decentralization had the greatest influence on lowering emissions at lower emissions quantiles and the least effect at higher emissions quantiles. The impact of environmental innovation, on the other hand, was lowest for lower emission quantiles and largest for higher emission quantiles. Economic growth and population increased carbon emissions, with the effect being greatest for lower emissions quantiles and lowest for higher emissions quantiles. The study further revealed that, the heterogeneous panel causality test supported a one-way causal connection, suggesting that any policy action including fiscal decentralization and environmental innovation had a considerable impact on carbon emissions.

\section{MATERIALS AND METHOD}

This study investigates the impact of revenue fiscal decentralization on environmental pollution control in Nigeria. The study covers a period from 2007 - 2020 and uses secondary form of data gathered from the sources identified on Table 1. The analytical tool used to test the impact of the Federal Government Independent Revenue (FGIR), State Government Independent Revenue (SGIR) and Local Government Independent Revenue (LGIR) on carbon dioxide emission $\left(\mathrm{CO}_{2}\right)$ management is the multiple regression technique. All independent variables are adjudged substantial at $5 \%$ level of significance. The logarithm values of all variables are applied for uniformity of values. The data on all independent variables are collected in their local currency while the $\mathrm{CO}_{2}$ Emission data are gathered in Million Tonnes from the World Data Atlas.

The regression model verified in this study is as presented below:

$$
\mathrm{CO}_{2}=\mathrm{f}(\text { FGIR, SGIR, LGIR) }
$$

where,

HDI =Human Development Index

FGIR $=$ Federal Government Independent Revenue $($ FG Tax effort)

SGIR = State Government Independent Revenue $($ SG Tax effort)

LGIR =Local Government Independent Revenue (LG Tax effort)
The above functional form is represented generically as follows:

$$
\mathrm{Y}_{1}=\alpha+\beta 1 X 1+\beta 2 X 2+\beta 3 X 3+\mu \mathrm{i}
$$

where:

$\mathrm{Y}_{1}=\mathrm{CO}_{2}$

$\mathrm{X}=$ Determinant of Carbon dioxide emission control

$\mathrm{X} 1=$ Federal Government Independent Revenue (FG Tax effort)

X2=State Government Independent Revenue (SG Tax effort)

X3=Local Government Independent Revenue (LG Tax effort)

$\beta=$ Determines the relationship between the independent variable $\mathrm{X}$ and the response

Variable Y or Gradient/slope of the regression measuring the amount of the change

In $\mathrm{Y}$ associated with a unit change in $\mathrm{X}$.

$\propto=$ Constant; $\mathrm{X}_{1}-\mathrm{X}_{3}=$ Regression coefficients; $\mu \mathrm{i}=$ Error term.

On the a priori, we expect; $\mathrm{X}_{1}>0, \mathrm{X}_{2}>0, \mathrm{X}_{3}>0$.

\begin{tabular}{|c|c|c|}
\hline Variable & Description & Data Sources \\
\hline $\mathrm{CO}_{2}$ & Carbon dioxide emissions & The World Data Atlas \\
\hline FGIR & $\begin{array}{l}\text { Federal Government } \\
\text { Independent Revenue }\end{array}$ & $\begin{array}{l}\text { CBN Annual Reports } \\
(2007-2020)\end{array}$ \\
\hline SGIR & $\begin{array}{l}\text { State Government } \\
\text { Independent Revenue }\end{array}$ & $\begin{array}{c}\text { CBN Statistical } \\
\text { Bulletin, } 2020 \text { edition }\end{array}$ \\
\hline LGIR & $\begin{array}{l}\text { Local Government } \\
\text { Independent Revenue }\end{array}$ & $\begin{array}{c}\text { CBN statistical } \\
\text { bulletin, } 2020 \text { edition }\end{array}$ \\
\hline
\end{tabular}

Table 1. Variables description and source

Source: Compilation by Author, 2021

\section{DATA ANALYSIS AND EXPLANATION}

The results of the data set's unit root test are shown in Table 2. The outcome verifies that the data collection is steady at order 1. Unit root is used to guarantee that the regression outcome of an inquiry is not fictitious. According to the descriptive statistics in Table 3 , the mean values for $\mathrm{CO}_{2}$, FGIR, LGIR, and SGIR are 1.99, 2.66, 1.46, and 2.79, respectively. $\mathrm{CO}_{2}$ has a maximum value of 2.06 and a lowest value of 1.89. In the same sequence, the highest FGIR, LGIR, and SGIR values are 3.02, 1.58, and 2.90, respectively. The standard deviation has a smaller spread, indicating that the data set clusters around the mean. Skewness values indicate a negatively skewed distribution. The Kurtosis and Jarque-Bera coefficients demonstrate that the data set is regularly distributed. The normality of the data distribution and model employed in this investigation is confirmed by Figure 1.

Table 2. Unit root test

\begin{tabular}{cccccc}
\hline VARIABLES & $\begin{array}{c}\text { ADF T- } \\
\text { STATISTIC }\end{array}$ & $\begin{array}{c}\text { MACKINNON CRITICAL } \\
\text { VALUE AT 5\% }\end{array}$ & $\begin{array}{c}\text { P- } \\
\text { VALUE }\end{array}$ & $\begin{array}{c}\text { ORDER OF } \\
\text { INTEGRATION }\end{array}$ & REMARKS \\
\hline LOGCO2 & -4.100773 & -3.212696 & 0.0133 & I(1) & STATIO- \\
NARY \\
LOGFGIR & -3.721443 & -3.144920 & 0.0194 & I(1) \\
NATARY \\
LOGSGIR & -6.939757 & -3.212696 & 0.0003 & I(1) \\
LOGLGIR & -4.422123 & -3.175352 & 0.0071 & I & NARY \\
STATIO- \\
NARY
\end{tabular}




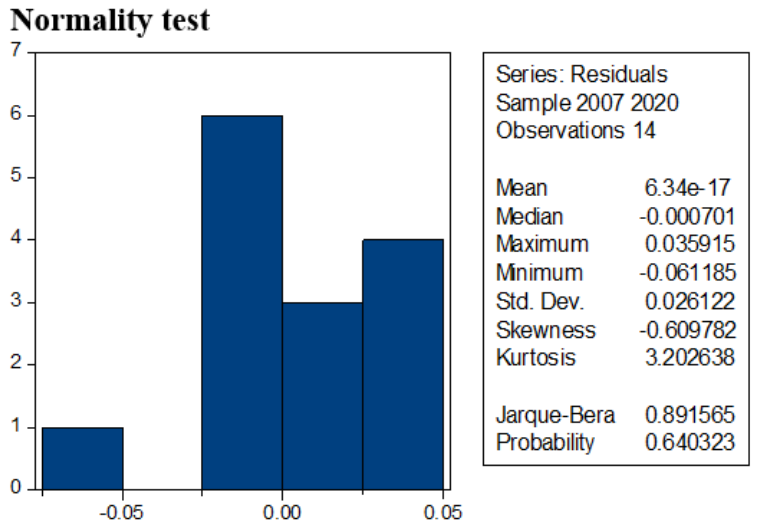

Figure 1. Histogram normality

In Table 4, $\mathrm{CO}_{2}$ shows a 64.7 percent, 72.6 percent, and 62.5 percent connection with FGIR, SGIR, and LGIR, according to the correlation analyses in Tables 3 and 4 . The connection with
SGIR is $1 \%$ significant, whereas the correlation between SGIR and LGIR is 5\% significant. Similarly, the association between $\mathrm{CO}_{2}$, SGIR, and LGIR is 64.7 percent, 41.8 percent, and 19.9 percent, respectively. Apart from $\mathrm{CO}_{2}$, the results show a very weak association with SGIR and LGIR, with p-values larger than $5 \%$. This outcome provides the impression that there is no concerted effort in the country to reduce $\mathrm{CO}_{2}$ emissions. That is, the central government and the subordinate governments do not work together to pool resources to combat environmental degradation, which has displaced many residents in several states, particularly the Niger Delta states. Furthermore, LOGSGIR shows a connection of 72.6 percent, 41.8 percent, and 68.2 percent with $\mathrm{CO}_{2}$, FGIR, and LGIR, respectively. The connection between $\mathrm{CO}_{2}$ and LGIR is substantial at the $1 \%$ level. With $\mathrm{CO}_{2}$, FGIR, and SGIR, LOGLGIR has 62.5 percent, 19.9 percent, and 68.2 percent, respectively. The connection between SGIR and $\mathrm{CO}_{2}$ is considerable, at $1 \%$ and $5 \%$, respectively. The link with FGIR, on the other hand, is small and weak.

Table 3. Descriptive statistics

\begin{tabular}{ccccc}
\hline & $\mathbf{C O}_{2}$ & FGIR & LGIR & SGIR \\
\hline Mean & 1.989361 & 2.657002 & 1.462248 & 2.794719 \\
Median & 1.988986 & 2.708274 & 1.462398 & 2.875630 \\
Maximum & 2.062206 & 3.016529 & 1.579784 & 2.903633 \\
Minimum & 1.895975 & 2.166537 & 1.322219 & 2.485721 \\
Std. Dev. & 0.049545 & 0.238700 & 0.078554 & 0.127248 \\
Skewness & -0.313096 & -0.448710 & -0.153208 & -1.169860 \\
Kurtosis & 2.302979 & 2.468142 & 1.973007 & 3.324826 \\
Jarque-Bera & 0.512140 & 0.634805 & 0.670020 & 3.254886 \\
Probability & 0.774088 & 0.728038 & 0.715331 & 0.196431 \\
Sum & 27.85106 & 37.19803 & 20.47147 & 39.12607 \\
Sum Sq. Dev. & 0.031911 & 0.740708 & 0.080220 & 0.210498 \\
Observations & 14 & 14 & 14 & 14 \\
\hline
\end{tabular}

Table 4. Correlation analysis

\begin{tabular}{|c|c|c|c|c|c|}
\hline & & LOGCO2 & LOGFGIR & LOGSGIR & LOGLGIR \\
\hline & Pearson Correlation & 1 & $.647^{*}$ & $.726^{* *}$ & $.625^{*}$ \\
\hline \multirow[t]{3}{*}{ LOGCO2 } & Sig. (2-tailed) & & .012 & .003 & .017 \\
\hline & $\mathrm{N}$ & 14 & 14 & 14 & 14 \\
\hline & Pearson Correlation & $.647^{*}$ & 1 & .418 & .199 \\
\hline \multirow[t]{3}{*}{ LOGFGIR } & Sig. (2-tailed) & .012 & & .137 & .494 \\
\hline & $\mathrm{N}$ & 14 & 14 & 14 & 14 \\
\hline & Pearson Correlation & $.726^{* *}$ & .418 & 1 & $.682^{* *}$ \\
\hline \multirow[t]{3}{*}{ LOGSGIR } & Sig. (2-tailed) & .003 & 137 & & .007 \\
\hline & $\mathrm{N}$ & 14 & 14 & 14 & 14 \\
\hline & Pearson Correlation & $.625^{*}$ & .199 & $.682^{* *}$ & 1 \\
\hline \multirow[t]{2}{*}{ LOGLGIR } & Sig. (2-tailed) & .017 & .494 & .007 & \\
\hline & $\mathrm{N}$ & 14 & 14 & 14 & 14 \\
\hline
\end{tabular}

Table 5. Symptomatic assessment results

\begin{tabular}{|c|c|c|c|}
\hline Fact-finding checks & F-statistics & P-value & Result Analysis \\
\hline Ramsey RESET - Stability test & 0.199 & 0.66 & $\mathrm{p}>0.05$ \\
\hline Breusch-Godfrey Serial correlation LM test & 0.379 & 0.69 & $\mathrm{p}>0.05$ \\
\hline Heteroskedasticity test & 0.305 & 0.82 & $\mathrm{p}>0.05$ \\
\hline $\begin{array}{c}\text { Normality test (Figure 1) - } \\
\text { Jarque-Bera }\end{array}$ & 0.891 & 0.64 & $\mathrm{p}>0.05$ \\
\hline Multi-Collinearity test: (Independent variables only) & Coefficient variance & VIF & $\begin{array}{c}\text { RESULT } \\
\text { ANALYSIS }\end{array}$ \\
\hline LOGFGIR & 0.0015 & 1.23 & $\mathrm{VIF}<10$ \\
\hline LOGSGIR & 0.0093 & 2.21 & $\mathrm{VIF}<10$ \\
\hline LOGLGIR & 0.0209 & 1.89 & $\mathrm{VIF}<10$ \\
\hline
\end{tabular}


Table 5 displays the results of numerous diagnostic tests to demonstrate the model's stability, normalcy, and lack of bias in this study. The Ramsey RESET test has a p-value larger than $5 \%$, confirming the model's stability. The model also lacks serial correlation, heteroskedasticity, and multicollinearity. The multi-collinearity test evaluated the interdependence of the independent variables, and with a Variance Inflation Factor (VIF) smaller than 10, there is no interdependence of the predictor variables employed in this study.

\section{ROBUSTNESS CHECK}
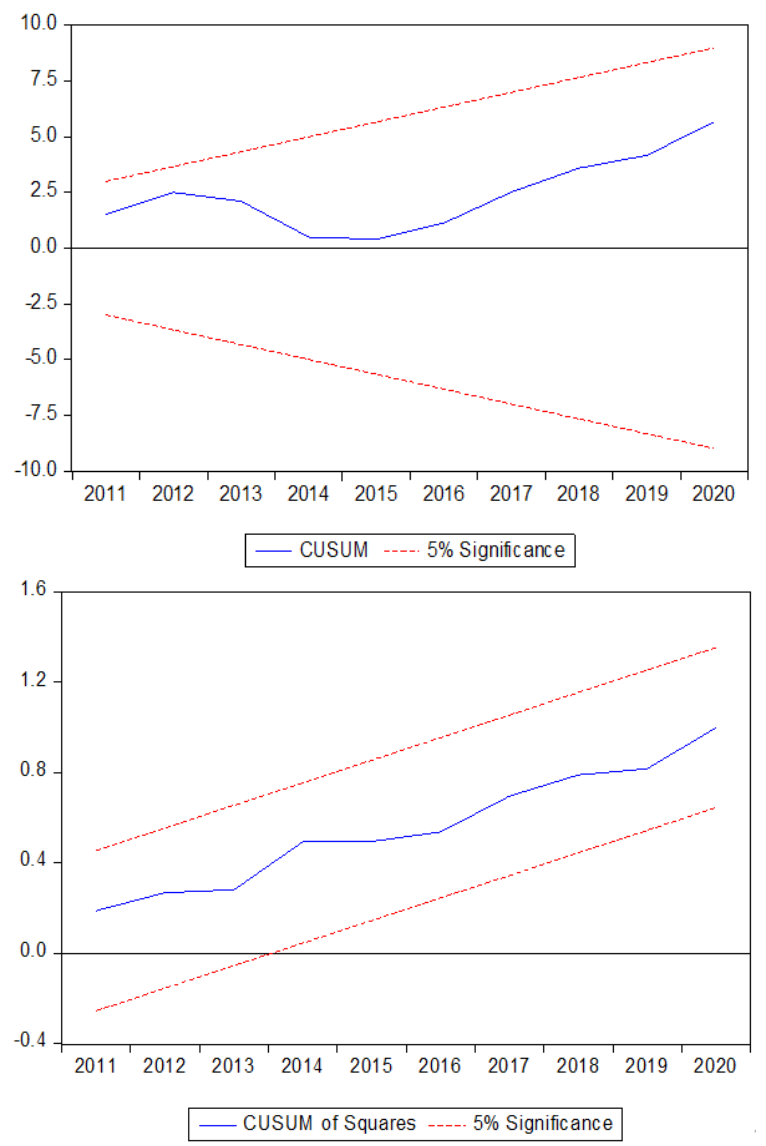

Figure 2. CUSUM test and CUSUM of squares

The robustness test, which uses the CUSUM test and the CUSUM of squares as shown in Figure 2, indicates that the model for this study is stable. The presence of the blue line in both images between the borders of the two dotted red lines indicates that the model is normal and unwavering. The Fstatistic in Table 6 further demonstrates its appropriateness by having a $\mathrm{p}$-value less than $5 \%$. The Durbin-Watson is within acceptable limits, and the R-squared indicates that fiscal decentralization accounts for 72.2 percent of changes in environmental pollution. However, there is an error-free forecast, as evidenced by the Standard Error of Regression being smaller than 1 as indicated in Table 6 . According to the t-statistic results, controlling pollution through the fiscal system is extremely difficult, as only the central government has a substantial beneficial impact on pollution management. The influence of state and municipal governments on $\mathrm{CO}_{2}$ emission reduction is negligible.

Table 6. Regression result

\begin{tabular}{|c|c|c|c|c|}
\hline \multicolumn{4}{|c|}{ Dependent Variable: LOG_CO} & \\
\hline \multicolumn{4}{|c|}{$\begin{array}{l}\text { Method: Least Squares } \\
\text { Sample: } 20072020\end{array}$} & \\
\hline Variable & Coefficient & $\begin{array}{l}\text { Std. } \\
\text { Error }\end{array}$ & $\begin{array}{c}\mathrm{t}- \\
\text { Statistic }\end{array}$ & Prob. \\
\hline LOG_FGIR & 0.093123 & 0.038410 & 2.424465 & 0.0358 \\
\hline LOG_LGIR & 0.198850 & 0.144906 & 1.372263 & 0.2000 \\
\hline LOG_SGIR & 0.125934 & 0.096486 & 1.305210 & 0.2211 \\
\hline $\mathrm{C}$ & 1.099217 & 0.187648 & 5.857856 & 0.0002 \\
\hline R-squared & 0.722010 & \multicolumn{2}{|c|}{ Mean dependent var } & 1.989361 \\
\hline $\begin{array}{l}\text { Adjusted R- } \\
\text { squared }\end{array}$ & 0.638613 & \multicolumn{2}{|c|}{ S.D. dependent var } & 0.049545 \\
\hline $\begin{array}{l}\text { S.E. of } \\
\text { regression }\end{array}$ & 0.029784 & \multicolumn{2}{|c|}{ Akaike info criterion } & $\begin{array}{c}- \\
3.954739\end{array}$ \\
\hline $\begin{array}{l}\text { Sum squared } \\
\text { resid }\end{array}$ & 0.008871 & \multicolumn{2}{|c|}{ Schwarz criterion } & $\begin{array}{c}- \\
3.772151\end{array}$ \\
\hline $\begin{array}{c}\text { Log } \\
\text { likelihood }\end{array}$ & 31.68317 & \multicolumn{2}{|c|}{ Hannan-Quinn criter. } & $\begin{array}{c}- \\
3.971641\end{array}$ \\
\hline F-statistic & 8.657506 & \multirow{2}{*}{\multicolumn{2}{|c|}{ Durbin-Watson stat }} & 1.623639 \\
\hline $\begin{array}{l}\text { Prob(F- } \\
\text { statistic) }\end{array}$ & 0.003938 & & & \\
\hline
\end{tabular}

\section{CONCLUSION AND SUGGESTION}

The study investigates the influence of Nigeria's fiscal system on pollution control. The research lasted from 2007 to 2020 and was evaluated using a multiple regression approach. First and foremost, the correlation analysis results suggest that the government is not making a concerted effort to reduce $\mathrm{CO}_{2}$ emissions. That is, the central government and the subordinate governments do not work together to pool resources to combat environmental degradation, which has displaced many people in a number of states, particularly those in the Niger Delta. The other tiers of government do not have the resources to address the environmental issues. As a result of the enormous duties of controlling pollution in the different quarters, the research suggests an equitable allocation of resources among the three levels of government, with a greater emphasis on the lower level of government. The lowest levels of government are located where the inhabitants live, which includes both rural and urban regions. Since of the large concentration of pollution in rural regions, they are best positioned to control the problem because they are near to the people and understand how acute their suffering seems. Furthermore, the government at all levels should ensure that environment policies and laws in the country should be well utilized to minimize the carbon emissions and other forms of environmental contamination.

This study suffers dearth of local studies which implies that researchers should endeavour to investigate the extent to which expenditure decentralization influences the prevention of carbondioxiode pollutions in the country. 


\section{REFERENCES}

[1] Kesidou, E., Demirel, P. (2012). On the drivers of ecoinnovations: Empirical evidence from the U.K. Research Policy, 41(5):

862-870.

https://doi.org/10.1016/j.respol.2012.01.005

[2] Lucas, R.E. (1988). On the mechanics of economic development. Journal of Monetary Economics, 22: 3-42. https://doi.org/10.1016/0304-3932(88)90168-7

[3] Zhou, K., Zhou, B., Yu, M. (2020). The impacts of fiscal decentralization on environmental Innovation in China. Growth and Change, 51: 169-1710. https://doi.org/10.1111/grow.12432

[4] Wang, D.L., Wan, K.D., Yang, J.Y. (2019). Measurement and evolution of eco-efficiency of Coal industry ecosystem in China. Journal of Cleaner Production, 209:

803-818

https://doi.org/10.1016/j.jclepro.2018.10.266

[5] Yu, Y., Liu, H.R. (2020). Economic growth, industrial structure and nitrogen oxide emissions reduction and prediction in China. Atmospheric Pollution Research, 11(7):

1042-1050 https://doi.org/10.1016/j.apr.2020.03.011

[6] Chakravarty, K., Kumar, S. (2020). Increase in energy efficiency of a steel billet reheating Furnace by heat balance study and process improvement. Energy Reports, 6: 343-349. https://doi.org/10.1016/j.egyr.2020.01.014

[7] Ma, X., Liu, Y., Wei, X., Li, Y., Zheng, M., Li, Y. (2017). Measurement and decomposition of energy efficiency of Northeast China-Based on super efficiency DEA model and Malmquist index. Environmental Science and Pollution Research International, 24(24): 19859-19873. https://doi.org/10.1007/s11356-017-9441-3

[8] Hadian, S., Madani, K. (2015). A system of systems approach to energy sustainability assessment: Are all renewables really green? Ecological Indicators, 52: 194206. https://doi.org/10.1016/j.ecolind.2014.11.029

[9] Sacchi, A., Salotti, S. (2016). A comprehensive analysis of expenditure decentralization and of the composition of local public spending. Regional Studies, 50(1): 93-109. https://doi.org/10.1080/00343404.2014.893387

[10] Oates, W.E. (1999). An essay on fiscal federalism. Journal of Economic Literature, 37(3): 1120-1149. https://doi.org/10.1257/jel.37.3.1120

[11] He, Q. (2015). Fiscal decentralization and environmental pollution: Evidence from Chinese panel data. China Economic Review, 36: 86-100. https://doi.org/10.1016/j.chieco.2015.08.010

[12] Que, W., Zhang, Y.B., Liu, S.B., Yang, C.P. (2018). The spatial effect of fiscal decentralization and factor market segmentation on environmental pollution. Journal of Cleaner Production, 184: 402-413. https://doi.org/10.1016/j.jclepro.2018.02.285

[13] Zhang, K., Zhang, Z., Liang, Q. (2017). An empirical analysis of the green paradox in China: From the perspective of fiscal decentralization. Energy Policy, 103:
203-211. https://doi.org/10.1016/j.enpol.2017.01.023

[14] You, D., Zhang, Y., Yuan, B. (2019). Environmental regulation and firm eco-innovation: Evidence of moderating effects of fiscal decentralization and political competition from listed Chinese industrial companies. Journal of Cleaner Production, 207: 1072-1083. https://doi.org/10.1016/j.jclepro.2018.10.106

[15] Lo, K. (2015). How authoritarian is the environmental governance of China? Environmental Science \& Policy, 54: https://doi.org/10.1016/j.envsci.2015.06.001

[16] Sigman, H. (2014). Decentralization and environmental quality: An international analysis of water pollution levels and variation. Land Economics, 90(1): 114-130. https://doi.org/10.3368/le.90.1.114

[17] Chen, X., Liu, J. (2020). Fiscal decentralization and environmental pollution: A spatial analysis. Discrete Dynamics in Nature and Society, pp. 1-10. https://doi.org/10.1155/2020/9254150

[18] Khan, Z., Ali, S., Dong, K., Li, R.Y.M. (2021). How does fiscal decentralization affect $\mathrm{CO}_{2}$ emissions? The roles of institutions and human capital. Energy Economics, 94: 105060. https://doi.org/10.1016/j.eneco.2020.105060

[19] Wang, Q., Su, C., Hua, Y., Umar, M. (2020). Can fiscal decentralization regulate the impact of industrial structure on energy efficiency? Economic ResearchEkonomska Istrazivana, 34(1): 1727-1751. https://doi.org/10.1080/1331677X.2020.1845969

[20] Guo, S., Wen, L., Wu, Y., Yue, X., Fan, G. (2020). Fiscal decentralization and local Environmental pollution in China. International Journal of Environmental Research and Public Health, 17: 1-17. https://doi.org/10.3390/ijerph17228661

[21] Zhou, C., Zhang, X. (2020). Measuring the efficiency of fiscal policies for environmental pollution control and the spatial effect of fiscal decentralization in China. International Journal of Environmental Research and Public Health, 17(23): 1-19. https://doi.org/10.3390/ijerph17238974

[22] Phan, C.T., Jain, V., Purnomo, E.P., Islam, M.M., Mughal, N., William, J. (2021). Controlling environmental pollution: dynamic role of fiscal decentralization in $\mathrm{CO}_{2}$ emission in Asian economies. Environmental Science and Pollution Research. https://doi.org/10.1007/s11356-021-15256-9

[23] Cheng, S., Fan, W., Meng, F., Chen, J., Liang, S., Song, M. (2021). Potential role of fiscal decentralization on interprovincial differences in $\mathrm{CO}_{2}$ emissions in China. Environmental Science \& Technology, 55(2): 813-822. https://doi.org/10.1021/acs.est.0c04026

[24] Lingyan, M., Zhao, Z., Malik, H.A., Razzaq, A., An, H., Hassan, M. (2021). Asymmetric Impact of Fiscal Decentralization and environmental innovation on carbon emissions: Evidence from highly decentralized countries. Energy \& Environment. https://doi.org/10.1177/0958305X211018453 